\title{
Factors that Determines the Success of Business Demon Value Added Management
}

\author{
Albert Irawan (Corresponding author) \\ Faculty of Business, Widya Mandala Catholic University \\ Jl. Dinoyo 42-44, Surabaya, 60265, Indonesia \\ Tel: 62-85733547178_E-mail: albert_mwigtech@yahoo.com
}

Received: March 19, 2014 Accepted: April 8, 2014

doi:10.5296/ber.v4i1.5325 URL: http://dx.doi.org/10.5296/ber.v4i1.5325

\begin{abstract}
The purpose of this paper is to provide a comprehensive indication of the Business Demon Value Added Management (BDVAM) as a form of Politics Governance Responsibility (PGR). This paper is to achieve its objectives by reviewing some relevant literature related to the five main areas of Business Demon Value Added Management (BDVAM) i.e revenue management, cost management, resource management, capital investment management, and sustainability. Through the above critical review of the existing literature, this paper on feature five factors that should be met as a condition for the successful practice of BDVAM, namely:(1) the amount of the commitment of business demon as a minority shareholder to suppress the majority shareholder of the company to solve operational problems, financial, political, social and environment with the help of the media, (2) the strength of militarist paradigm adopted by the business demon, (3) the ability of business demon to do coopetition, which is able to provide added value for shareholders and stakeholders, (4) the ability of business demon meet its working capital with an unlimited source of funds, (5) the ability of business demon builds mutual benefits with government bureaucrats and suppliers. From the previous paper discussed more success in the role of business angel in providing added value for the company. This paper focuses on the business demon by introducing five prepositions that can improve the performance of the company. This literature is limited only to answer five fundamental questions: (1) why the business demon success or failure in applying BDVAM? (2) what are the internal and external factors that are needed to qualify at the time of applying BDVAM, (3) how to improve and discrepancies in stock prices, while the growing political rents, interest in working at the company worker's is reduced because of the inability of the business demon? (4) the opinion of the author, which one is better between
\end{abstract}


business demon and business angel in adding value? (5) how to improve the model BDVAM that this model does not become BDVDM (Business Demon Value Destruction Management), where business demon has dominant rols in setting the company's stock price. The previous paper discussed more on the role of business angel in providing value added and nothing that specifically addresses the business demon who has political connections with government. The first contribution of this paper to the existing literature can be found that the relationship BDVAM with operational performance, financial, political,social and environment is still not widely studied. Second, this paper adds to the literature on entrepreneurial finance in particular how BDVAM could be an alternative strategy for the business demon in the plan will be to invest in the company. Also in this paper introduces Business Demon Value Destruction Management (BDVDM), which is a management concept that states that the business demon success is providing value to the business angel and other shareholder to buy an existing company or merged with other similar companies, as well as influencing stakdeholders to close the company if there is a discrepancy in a process that could harm customers in the long term.

Keywords: Business Demon Value Added Management (BDVAM), Business Demon Value Destruction Management (BDVDM), Politic Responsibility, Entrepreneurial Finance.

\section{Introduction}

A number of studies concerning entrepreneurial finance now many done and narrowly focused more on venture capital and will involve an informal investor/angel investors (Brophy and Shulma,1992; Saint Pierre and Mathieu, 2003; Denis,2004; Rassoul,2006; Lantz and Sahut, 2009; Redis, 2009). Research on an informal investor/angel investors itself has also been developing countries with a discussion as follows:

\subsection{Demography Informal Investor/Angel}

a. Country of origin informal investor/angel investors are based on continent:

i. Asia and Australia (Hindle and Wenban,1999; Tashiro, 1999; Hindle and Lee,2002; Kutsuna and Harada, 2004; Gunawan,Wessiani, et al., 2011; Scheela and Isidro, et al.,2012).

ii. United States (Harr, Starr, and MacMIllan,1998; Aram, 1989; Wetzel, 1981,1983,1994; Duxbury, Haines, and Riding,1996; Freear, Sohl, and Wetzel, 1997; Korhonen,2009)

iii. Europe (Mason, Harrison, and Chaloner, 1991; Mason and Harrison, 1994,1996; Van Osnabrugge,1998; Kelly, 2000; Stedler and Peters, 2003; Paul, Whittam, and Johnston,2003)

iv. Africa (Curtis, 2003)

v. Nordic (Landstrom, 1992,1993,1995,1998; Suomi and Lumme, 1994; Reitan and Sorheim,2000; Sorheim and Landstrom,2001)

vi. Middle east region (Curtis,2003; The Economist,2013) 
b. Age (Gaston,1989; Freear, Sohl and Wetzel,1991,1994; Van Osnabrugge and Robinson,2000; Hill and Power,2002; Autio and Arenius, 2003)

c. Sex (Gaston,1989, Freear,Sohl and Wetzel,1991; Wetzel and Freear,1996)

d. Number of assets owned (Gaston, 19891 Benjamin and Margulis,2001)

e. Experience managing multinational companies (Aram,1989; Gaston,1989; Sullivan, 1991; Van Osnabrugge and Robinson,2000; Autio and Arenius, 2003)

f. Level of competency (Sorheim and Landstrom,2001)

g. The level of formal education possessed (Aram,1989; Gaston,1989; Van Osnabrugge and Robinson,2000; Hill and Power,2002)

1.2 Characteristics of Informal Investment Transactions between the Investor/Angel Investor with the Company

h. The size of investment (Aram, 1989; Gaston,1989; Freear,Sohl and Wetzel,1991; Linde and Prasad,2000; Van Osnabrugge and Robinson,2000; Hill and Power,2002)

i. Frequency investing (Gaston,1989; Freear and Wetzel,1991; Sullivan,1991; Freear, Sohl and Wetzel,1992)

j. Geographic to invest (Aram,1989; Riding and Short,1987; Freear, Sohl and Wetzel,1992;1994; Lerner,1998; Benjamin and Margulis, 2001; Hill and Power,2002)

k. Viable industries for investments (Wetzel,1983; Aram,1989; Gaston,1989; Freear,Sohl and Wetzel,1995; Van Osnabrugge and Robinson,2000; Hill and Power,2002)

1. Object of investments in new/early stage of operation (Aram,1989; Freear and Wetzel,1989; Freear, Sohl and Wetzel,1996; Sohl,2004)

m. Family companies funded by business angel has survived to the third generation (Beckhard and Dyer,1983; Dyer and Sanchez,1998; Athanas-siou and Crittenden,2000; Filbeck and Lee,2000; Sonfield and Lussier,2004)

\subsection{The investment process is done by informal investor/angel investors}

n. Sourcing/Co-Investing (Aram,1989; Freear, Sohl, and Wetzel,1990; Kelly and Hay,1996; Van Osnabrugge and Robinson,2000; Benjamin and Margulis,2001)

o. Dilligence process (Harrison, Dibben and Mason,1997; Van Osnabrugge and Robinson,2000; Linde and Prasad,2000)

p. Contract structure (Freear, Sohol and Wetzel,1992; 1995; Van Osnabrugge and Robinson,2000) 
1.4 In Some Studies Explained That Some Companies Belonging To The Family Business Angel Funded By Business Angel (Krueger, 1974; Davis, 2001; Hunt, 2002; Crispin, 2002)

\subsection{Motivation Investments Made by Angel Investors}

q. Rate of return on investment can be financially profitable or financially provide added value (Fama and Miller, 1972; Gaston,1989; Sullivan and Miller,1990; Freear,Sohl and Wetzel,1995; Van Osnabrugge,1998;2000; Linde and Prasad,2000; Benjamin and Margulis,2001; Ardichvili et al., 2002; Hill and Power,2002; Madill et al., 2005; Munck and Saublens,2005; Politis,2008)

r. Investment holding period (Gaston,1989; Freear,Sohl and Wetzel,1995; Van Osnabrugge,1998; Linde and Prasad,2000; Benjamin and Margulis,2001; Hoontrakul, 2001)

s. Can provide added value in non-financial benefit (Freear, Sohl and Wetzel,1995; Sullivan and Miller,1996; Linde and Prasad,2000; Van Osnabrugge and Robinson,2000; Sorheim,2005; Politis,2008; Ragnar, Marius, and Lars,2012)

t. Want to destroy the company (Berglas,1998; Cockerill, 2002; Ibrahim,2008)

Although the presence of the business angel has been long enough to present as a minority shareholder in the company and has been widely discussed in several previous studies, still could not prevent a global financial crisis. The global financial crisis that is happening around the world lately made two contrasting events: (1) a newly established company with the support of the business angel through still not able to survive (McCarthy,Solomon and Mihalek,2012). This is because of politic responsibility policy are not going well (Manzoor,2013) and busness angel can't give a good contribution though trying to provide added value and therefore contributes to the quality of the financial statements and the quality of the company's revenue (Jin and Myers,2006; Politis,2008; Lee and Seo,2009; Gul, Kim and Qiu,2010; Piotroski, Wong, and Zhang,2010; Ragnar,Marius, and Lars, 2012); (2) it is not overly impact on large companies because of the complicated relationship between political connections with the countries major companies where the majority of CEOs are former civil servants or government officials (Lantz, Montandrau, Sahut,2010) as well as the active involvement of business demon the shareholding structure of the company (Bates,2009; Zalzman,2013; Anonymous, 2014).

With the active involvement, business demon replace the company's management system into a militaristic nature (Talbot,2003), making the resolution of shareholders and change political responsibility policy on large firms (The Economist,2007). However the business demons still remains to be watched by other shareholders and the board of the company because they invest so much capital not only as a minority shareholder, but has a high motivation to seek compensation, acquire stakes of other shareholders with a negative impact to the company so that it can acquire/sell the company at a higher price, but it also forces them to engage directly, although not knowing the problems related to the activity of the operational details that could be dangerous if the payments are restricted, the onset of the debt, the sale of assets, 
changes in corporate control agreement (Bennett,2008; Rose,2010).

The business demon and other stakeholders to learn from the global financial crisis that has occurred previously (Friedman and Schwartz,1963; McCarthy, Solomon, and Mihalek,2012) and do not believe the board of the company as previously they often ask a very high compensation package without any clear indicators, change the policy of Good Corporate Governance and dominate corporate board, and can't create added value and inhibit a change in strategy from outside the company (Corlette,19891 Paul and Lydenberg,1992; Davidson, Worrell, and Jelly,1995;Frooman,1999; Graves,Rehbein,and Waddock,2001; Rowley and Moldoveanu,2003; Lipton,2007; Myles,2011; Manzoor,2013; The Economist,2013).

The presence of the business demon to create shareholder resolutions and bring changes to the company(The Economist,2007). Business demon will use all its resources to provide added value to influence the management of the company such as (1) when the shareholder's meeting, business demon will ask the company's performance in detail and how the board and the audit committee control their staffs, (2) questioning why returns for shareholders when the little cash that the company very much, (3) alter the fundamental role of the board of the company is bad and unproductive, (4) degrading the performance of accountants, auditors through a board meeting, (5) create pressure on the board of the company to manage the short-term stock price performance rather than long-term value creation because the company's board of storing information for himself and ask who controls the performance of the board of the company (Lipton,2007; The Economist,2007; Tilson and Heins,2011; Kelly,2013).

Therefore Business Demon Value Added Management (BDVAM) is an important issue for the company's corporate board anticipation these days due to the presence of business demon: (1) involve the media to tell all the performance of the board of the company and all employees in the company, (2) change of control that was once performed by the board of the company, (3) makes the role of the board of the company to be reduced due to the inclusion of expert consultants/experts/members bureaucrats who still/not to give independent advice for business demon don't trust the vision of the CEO, (4) support the workings of the CEO and the management to run the business and support in case of problems will be revoked and the CEO and the management should resign (Gray,2003; Myles,2011).

In general, BDVAM is a management concept which states that the success of a company depends on the ability of business demon (is angel investors from the religious/environmental group/community based organizations/group of a certain profession/group union/group of rich people who have a minority shareholding companies in many countries who want to do a shareholder resolution at a company to exert pressure on the board of the company to change practices of the company,besides having a very close relationship ties with high-ranking officials at state-owned banks or central/local government (Gaston,1989) in the revenue process optimization, cost management, resource management, management of investment capital, and the management of environmental damage and social problems in the community about where the company is located (Shleifer and Vishny,1994; MacGregor and Campbell,2008; Tilson and Heins,2011; Ameer and Othman,2012). In its development, 
BDVAM strongly associated with corporate governance (Sussland,2004;Ting,2006; Lipton,2007; The Economist,2007; Myles,2011), the concept of Bottom Line (Gee,2002), the relevant debate between economism and militarism paradigm adopted by the business demon in the company (Hoskin and Macve,1990; Cloke and Goldsmith,2002; Talbot,2003).

From some research findings indicate that BDVAM is a concept that is very easy to understand, but very difficult to implement in order to be successful, because there is a motivation of business demon in the ease of running the company get through government policies that support/investment contract package from the government, in return the company must provide political support and sound (Fisman,2001; Husnan,2001;Mobarak and Purbasari,2001; Faccio,2006). From the perspective of business demon,it is generally agreed that the operational, financial,political,social and environment problems are important issues and could affect stock price synchronicity and the company's stock price crashes (Stingler,1971; Jin and Myers,2006; Hutton,Marcus and Tehranian,2009; Piotroski,Wong, and Zhang,2010), but the business does not give enough attention to the business demon on these issues (Shleifer and Vishny,1994; Steven,1998; Ibrahim,2008; MacGregor and Campbell,2008; Cheffins and Armour,2011). Of some of the findings from previous research, the purpose of this paper is to provide a comprehensive indication of the value added elements of the business demon and actions that affect stock price synchronicity and the company's stock price crashes. It is supported by four fundamental questions trying to be answered to achieve the objectives of this paper are: (1)why the business demon success or failure in applying BDVAM?, (2) what are the internal and external factors that are needed to quality at the time of applying BDVAM, (3) how to improve and discrepancies in stock prices, while the growing political rents, interest in working at the company's workers is reduced because of the inability of the business demon with a high political?, (4)the opinion of the author, which one is better between business demon and business demon on the value added?, (5) how to improve the model BDVAM that this model does not become Business Demon Value Destruction Management (BDVDM), where business demon has a dominant role in setting the company's stock price, and could force the owners to sell the company's assets before other business to be owned by the business demon (Benoit,2014; Benoit and Chung,2014)? The answer of these questions are very important to strengthen the argument that BDVAM is an ideal concept that can be used by informal investors in making investment decisions.

\section{Literature Review}

\subsection{Business Demon Value Added Management (BDVAM) and Politic Responsibility (PR)}

PR in a company is very important in influencing the performance of the company not only in emerging countries but also in developed countries (Fisman,2001). PR is essential to set shared between business demon, the other shareholders, the board of the company and the government because of corruption prone causing uncertainty for businesses and increase the cost of business transactions (Habib and Zurawicki,2002,2005). There is no direct involvement in several companies that stumble legal issues, government and political party supporters tend to support government actions affecting business demon in the shareholders of the company in order to depress the company's board to achieve a good profit support 
voice and money to win elections (Sutter,1999; Davis,2001; Fisman,2001; Crispin,2002; Hunt,2002; Kapner,2003; Manzoor,2013) and also joined hands with the corrupt that increase uncertainty, increasing the costs of cross border business transactions (Habib and Zurawicki,2002,2005; Faccio,Masulis, and McConnell,2006; Nelson,2012).

Board of the company has a strong influence on the company to change the PR policy, affecting the company's stock price and hide negative information resulting in stock price synchronicity and the company's stock price crashes (Stingler,1971; Jin and Myers,2006; Hutton, Marcus and Tehranian,2009; Piotroski, Wong, and Zhang,2010).Often companies take advantage of the information asymmetry Council corporate performance as a negative signal for the company(Bhattacharya,1979; John and Williams,1985; Miller and Rock,1985). This affects the company does not distribute dividends for shareholders when the company's profit and have cash that very much, and vice versa (Sembenelli,1993; Moyer,Rao, and Regnard,1996; Gombola and Feng-Ying,1999; Tim, Nahum, and Xiaojing,2010).

BDVAM concept is increasingly believed to be the truth as a result of the global financial crisis around the world provide a signal that is the attitude of the board of the company during the company does not pay attention to the stakeholders and not give protection to their shareholders and themselves act as if they have the ability to manage the company's better than business demon. The company is a member of the community for survival which is funded by the public (shareholders particularly business demon). Therefore to give a sign to the board of the company in order to work more carefully then business demon at the time of any meeting of shareholders of the truth of the information requested examined the performance of the company by an independent consultant (Graves, Rehbein, and Waddock,2001; Adegbite,Amaeshi, and Amao,2011). During its development, BDVAM directly related very closely to the concept of Politic Responsibility (PR), which is the intention of the board of the company to commit a crime is difficult to be identified, which could be more easily identified is the lack of awareness of the risks, the lack of responsibility of overseeing the company's operations (French,1984; Goodpaster,1983; Velasquez,1983; Ranken,1987; Gibson,1995; Wilmot,2001). A company is required to maintain the continuity of the shareholders and stakeholders, therefore by all means necessary to bring about change business demon by providing added value that can be favorable the company.

With the concept BDVAM help business demon to focus on the politics of responsibility in five key areas, namely the management of income or revenue optimization process (Talluni and Van Ryzin,2005; Yu,Wee,and Su,2012; Fernandez,2012;Hasan,2013), cost management (Anderson and Dekker,2009; Piontkowski et al.,2012), resource management (Boselie, Dietz and Boon,2005; Belak, Ajinovic Barac, and Tadic,2009; Tadic,2010; Zeghal and Maaloul,2010), capital investment management (Huang et al., 2009; Zhao,2011), sustainability (Rahardjo et al., 2013), Politic Responsibility is a commitment to responsible business demon on the negative effects caused by the company's operations (Carroll,1991; Jones et al., 2009a; Burr,2012; Nelson,2012). Politic Responsibility is a consequence of a company when running concept BDVAM. 


\subsection{Results of Empirical Research of BDVAM}

The concept of BDVAM on the basic is how to offer board of a company's stock price increases between $30 \%$ to $50 \%$. This concept is a concept, which is logically easy to understand but difficult to practice. This is the conclusion of various research results.

BDVAM idealism stated that the company that can implement the BDVAM will be able to bring a shareholder resolution and support of all stakeholders so that the impact on the company's good performance. Nevertheless, Caton,Goh, and Donaldson (2001) in their research are illustrated in Table 1 show that the implementation of Business Demon Value Added Management (BDVAM) not always able to improve the performance of the company, even from samples of the company there is no effect at all, and no effect of an increase in performance, but not all the parts (such as corporate social performance, financial performance,etc).

Table 1. Various Research Results on The Relationship of Business Demon Value Added Management (BDVAM) and Corporate Performance (CP)

\begin{tabular}{|l|l|}
\hline Results & Author(s) \\
\hline BDVAM activities enhance the corporate performance & $\begin{array}{l}\text { Filippello, 1993; Del Guercio and Hawkins, 1999; } \\
\text { Gillan and Starks, 2000; English } \text { et al., 2004; Nelson, } \\
2006 ; \text { Brav et al., 2008; Del Guercio et al., 2008; } \\
\text { Greenwood and Schor,2009; Kim } \text { et al., 2009; Klein } \\
\text { and Zur, 2009; Lee and Park, 2009; Becht et al., } \\
2010 ; \text { Cheng et al., 2010; Ertimur et al., 2010; } \\
\text { Barach Aljinovic, et al., 2013. }\end{array}$ \\
\hline $\begin{array}{l}\text { BDVAM activities do not influence the corporate finance because } \\
\text { business demon gets resistance from other shareholders and the board } \\
\text { of the company who could not get a good performance boost moments } \\
\text { when should remove the subsidiary company or unproductive assets or } \\
\text { merge }\end{array}$ & $\begin{array}{l}\text { and Yeung,2004; Barber, 2006; Del Guercio et al., } \\
\text { Kaplansky and Levy,2010. }\end{array}$ \\
\hline $\begin{array}{l}\text { BDVAM activities only enhance a part of corporate performance } \\
\text { and Starks, 2007; }\end{array}$ & $\begin{array}{l}\text { DeAngelo and DeAngelo,1989; Gordon and Pound, } \\
1993 ; \text { Solh, 2000; Turner, 2007; Lublin, 2011; Burr, } \\
2012 .\end{array}$ \\
\hline
\end{tabular}

Also according to Rehbein, Waddock, and Graves (2004) expose (illustrated in Table 2) that the BDVAM on the application by business demon closely related to the stakeholders (shareholders, employees, community and environment) in the goal achieving company performance. Business demon in the process of adding value for the company must pay attention to the sustainability of the existing stakeholders (Tilson and Heins, 2011).

Table 2. Various Research Results on The Relationship of implementation of Business Demon Value Added Management (BDVAM) by a Business Demon and The Stakeholders

\begin{tabular}{|l|l|}
\hline Results & Author(s) \\
\hline $\begin{array}{l}\text { BDVAM activities conducted by Business Demon } \\
\text { relating to shareholders including Business Angel }\end{array}$ & $\begin{array}{l}\text { Vogel, 1983; Filippello, 1993; Turner, 2007; Budsaratrahoon, } \\
\text { Lhaopadchan, and Hillier, 2010 }\end{array}$ \\
\hline
\end{tabular}




\begin{tabular}{|l|l|}
\hline $\begin{array}{l}\text { BDVAM activities conducted by Business Demon } \\
\text { relating to employees }\end{array}$ & $\begin{array}{l}\text { Huselid, 1995; Becker and Gerhard, 1996; Huselid, Jackson and } \\
\text { Schuler, 1997; Ichnioski and Shaw, 1999; Pfeffer and Veiga, } \\
1999 ; \text { Burton and O'Reilly, 2000; O'Reilly and Pfeffer, 2000; } \\
\text { Bezemer, Peij, et al, 2010 }\end{array}$ \\
\hline $\begin{array}{l}\text { BDVAM activities conducted by Business Demon } \\
\text { relating to communities }\end{array}$ & $\begin{array}{l}\text { Waddock and Graves,1997b; Agle, Mitchell, and } \\
\text { Sonnenfield,1999; Burke, 1999; Rochlin and Christoffer, 2000; } \\
\text { Hillman and Keim, 2001 }\end{array}$ \\
\hline $\begin{array}{l}\text { BDVAM activities conducted by Business Demon } \\
\text { relating to customers }\end{array}$ & Miles,1987; Waddock and Graves,1997a,1997b \\
\hline $\begin{array}{l}\text { BDVAM activities conducted by Business Demon } \\
\text { relating to environment }\end{array}$ & Feldman, Soyka, and Ameer,1997 \\
\hline $\begin{array}{l}\text { BDVAM activities conducted by Business Demon } \\
\text { relating to officials who sit on the government of a } \\
\text { country where the company is domiciled }\end{array}$ & Purwoto,2011 \\
\hline
\end{tabular}

\section{Discussion}

The diversity of research results and the differences between how the shareholder raises the question of why a company successfully implemented BDVAM (Business Demon Value Added Management) and why other companies do not reap good performance despite applying BDVAM? Do Business demon too dominant influence causing BDVAM transformed into BDVDM (Business Demon Value Destruction Management). Following questions increase five factors that must be considered in order to successfully implement BDVAM namely: (1)the relationship of capital owners and managers of capital, (2) militarized paradigm adopted by the business demon, (3) direct involvement of representatives of the Commission Eradication of Corruption and the people in the company, (4) the ability of the business angel transformed into business demon, in the relationship with the company's stakeholders, (5) internal and external conditions that affect business demon is not running BDVAM but running BDVDM.

\subsection{Attitudes of Business Demon On Minority Shareholder Issues}

From the view of agency theory, the company that owns many subsidiaries in the relationship can be characterized as a principal-agent relationship. In this perspective, it is recognized that the interests of local subsidiaries may not always be aligned with the parent company due to the different motivations in giving values between company boards and shareholders of each company, a subsidiary even though the law should have the same perception of the purpose of the board of the company and shareholders of the parent company (Gupta and Govindarajan,2001,2002). This is supported study conducted Eisenhardt (1989) and Rose (2010) was also explained that the common difference between the perception of the company's board by the shareholders because in the opinion of the board of the company, the shareholders are not entitled to intervene on the following issues can it can be resolved. These issues are as follows:

1. Revenue issues. 
a. Often the board of the company are too high set the price of the new product regardless of whether the product can be sold in the market and preferred by the customer or not. In addition the product is often packaged and sold at a cheap price without giving good service

b. Often the company's board more use of internal capital firms without considering the use from capital markets or financial institutions

c. Often the board of the company to buy assets remain unproductive without considering cooperation with investors

2. Cost management issues.

a. Often the board of the company not recorded correctly corporate spending and do relocation resources are not in accordance with customer needs

b. Often the board of the company in the process of re-engineering the product and service offerings have nothing to do with the needs of the customer

3. Human resource management issues.

a. Often the board of the company doesn't give reasonable attention to its human resources when recruiting new employees or put the old employees are not in the right position according to his/her ability

4. Investment capital management issues

a. Often the board of the company doesn't invest in assets that can be quickly converted into profit

5. Environmental issues

a. Often the board of the company is not sensitive to implementation waste $\mathrm{q}$ management and keep the company's production process not to pollute the environment with eco-friendly activities

6. Social issues

a. Oten the board of the company is not sensitive to social issues in the community. Moreover allocate less profit firms to assist communities that are still undeveloped.

Business demon has taken the role to influence other shareholders through letter or at the shareholder's meeting have noticed that during this political governance and its subsidiary companies not properly managed by the board of the company that made the unilateral decision by the company's board. Some of the steps by the business demon different from those of the previous business angel as illustrated by a study conducted by Lin \& Lin (2014) and Ragnar, Marius, and Lars (2012), which as illustrated in Table 3 that there are two activities, namely intra-organizational (relation relation to external company) and inter-organization (relating to internal company) that can be performed by minority 
shareholders.

Table 3. Differences Activity Value Added conducted by Business Angel and Business Demon

\begin{tabular}{|c|c|c|c|}
\hline $\begin{array}{l}\text { The level of direct } \\
\text { involvement }\end{array}$ & Category & Intra-Organizational Activities & Inter-Organizational Activities \\
\hline Low & Strategy & & \\
\hline Business Angel & & $\begin{array}{l}\text { a. Provide input strategic decisions } \\
\text { b. Provide direction for the } \\
\text { formulation of a marketing plan and } \\
\text { work program entities and } \\
\text { subsidiaries }\end{array}$ & $\begin{array}{l}\text { a. Participate approved the election } \\
\text { of the board of the company }\end{array}$ \\
\hline Business Demon & & $\begin{array}{l}\text { a. Provide a list of investors who want } \\
\text { an investment cooperation } \\
\text { b. Recruiting independent consultant } \\
\text { and independent auditors to assist in } \\
\text { the formulation of marketing plans } \\
\text { and work programs }\end{array}$ & $\begin{array}{l}\text { a. Offer candidates commissioners } \\
\text { and the board of directors of } \\
\text { government/military/ other } \\
\text { companies that have been } \\
\text { successful in }\end{array}$ \\
\hline Intermediate & Support & & \\
\hline Business Angel & & $\begin{array}{l}\text { a. Have the ability to } \\
\text { marketing,economics, taxation and } \\
\text { accounting } \\
\text { b. Take on the role as motivator and } \\
\text { facilitator for the board of the } \\
\text { company }\end{array}$ & $\begin{array}{l}\text { a. Industry know-how } \\
\text { b. Customer and Partner processes } \\
\text { c. Further financing } \\
\text { d. Get involved in the recruitment } \\
\text { board of the company }\end{array}$ \\
\hline Business Demon & & $\begin{array}{l}\text { a. Ask the company to pay more taxes } \\
\text { and help the government in } \\
\text { community activities through the } \\
\text { products owned } \\
\text { b. Encourage local and foreign } \\
\text { investors to become shareholders of } \\
\text { the company and to the } \\
\text { establishment of a new business } \\
\text { venture } \\
\text { c. Having the ability to mergers and } \\
\text { acquisitions as well as having } \\
\text { experience in the stock split and the } \\
\text { merger of the company and has a } \\
\text { capital market investment broker } \\
\text { connections }\end{array}$ & $\begin{array}{l}\text { a. Making negative news about the } \\
\text { company to replace the board of a } \\
\text { company that has poor } \\
\text { performance } \\
\text { b. Forcing investment idea to take } \\
\text { off unproductive assets/sell a } \\
\text { subsidiary that do not perform } \\
\text { well and give advice to the } \\
\text { company buy a large stake in the } \\
\text { company as a form of financing }\end{array}$ \\
\hline High & $\begin{array}{l}\text { Operational } \\
\text { Management }\end{array}$ & & \\
\hline Business Angel & & $\begin{array}{l}\text { a. Assist provide input on both } \\
\text { corporate }\end{array}$ & $\begin{array}{l}\text { a. Participate approve compensation } \\
\text { to the board of the company }\end{array}$ \\
\hline
\end{tabular}




\begin{tabular}{|c|c|c|c|}
\hline & $\begin{array}{l}\text { b. } \\
\text { c. }\end{array}$ & $\begin{array}{l}\text { management application systems } \\
\text { implementation, operational } \\
\text { reporting } \\
\text { Participate in any meetings with } \\
\text { customers } \\
\text { Participate in every price formation } \\
\text { and also participate sell products to } \\
\text { customers }\end{array}$ & $\begin{array}{l}\text { including the CEO when reaching } \\
\text { the target company }\end{array}$ \\
\hline Business Demon & $\begin{array}{l}\text { b. } \\
\text { c. } \\
\text { d. }\end{array}$ & $\begin{array}{l}\text { Participate in the development of } \\
\text { new products } \\
\text { Participate in the exhibition of } \\
\text { products and work with the media } \\
\text { for the publication of the company } \\
\text { activities } \\
\text { Participate government tenders } \\
\text { Cooperation with other companies } \\
\text { and undertake joint work effort in } \\
\text { serving the customer to a product } \\
\text { that is created } \\
\text { Working closely with the company's } \\
\text { competitors to exchange information } \\
\text { and create a contract of employment } \\
\text { about which areas to work on } \\
\text { together and which areas should be } \\
\text { done every company }\end{array}$ & $\begin{array}{l}\text { a. Changing existing company } \\
\text { policies and make new provisions } \\
\text { that benefit shareholders } \\
\text { b. Replacing the majority of people } \\
\text { who sit on the board of the } \\
\text { company with outsourced } \\
\text { labor/management consultant } \\
\text { independent from the government } \\
\text { or a seasoned professional } \\
\text { c. Questioning large corporate board } \\
\text { compensation, performance is less }\end{array}$ \\
\hline
\end{tabular}

Of the few studies that have been conducted, presenting that on average, five years later after business demon involved the results are stock price and operating performance of the target company is more powerful than similar competitor company (Anonymous, 2014; Benoit, 2014). Based on the description, the first proposition is business demon commitment to press the board of the company with the implementation of Business Demon Value Added Management (BDVAM) according to which best suits the desire to direct involvement in the company is very desirable.

\subsection{Militerism Paradigm and Business Demon Value Added Management}

Talbot (2003) and Barac, Aljinovic, et al., (2013) states that at the time the company plans to expand, business demon with a militaristic nature should be able to be responsive to provide value added services such as (1) providing input expansion of sales of products, goods and services, (2) ask the board of the company for implementing cost effective strategies, (3) asking the board to increase the company's competence and value of human resources (4) asking the board for carrying out new projects even asked to sell the subsidiary entities or assets that are not productive. In addition the company is currently experience a recession, business demon with a militaristic nature should be able to be responsive to provide value added services such as (1) entry into new business activities which could give positive return 
expectations, (2) significantly cut fixed costs of capital investment been invested, (3) providing training to management and employees and partners relating to new business activities are conducted, (4) invite government representatives to sit on the board of the company as well as to replace the company's board is not working well.

By applying militaristic by business demon, Talbot (2003) concluded as illustrated in Table 4 that the board of the company will be able to improve the performance of the company. Forcing the ideas of business demon expected to bring about change and how to view previous companies where shareholder engagement less. Often found business demon connected political conduct that destroy the value of the manifestation of opportunism (Foss et al., 2003) because of too much influence exerted so as to form a power that can not be touched by other stakeholders.

Table 4. Militarism Paradigm and Its Relationship with BDVAM

\begin{tabular}{|c|c|c|}
\hline $\begin{array}{l}\text { Militarism } \\
\text { Paradigm }\end{array}$ & $\begin{array}{l}\text { Implementation of Business Demon Value Added } \\
\text { Management (BDVAM) }\end{array}$ & $\begin{array}{l}\text { Implementation of Business Demon Value Destruction } \\
\text { Management (BDVDM) }\end{array}$ \\
\hline \multicolumn{3}{|l|}{$\begin{array}{l}\text { Narrow } \\
\text { orientation of }\end{array}$} \\
\hline Business angel & $\begin{array}{l}\text { a. Economic paradigm is more commonly used to } \\
\text { achieve maximum corporate profits and little } \\
\text { implementation humanist attitude }\end{array}$ & $\begin{array}{l}\text { a. Political paradigm dominates because it could } \\
\text { affect the company's board in order to work in } \\
\text { accordance with the wishes }\end{array}$ \\
\hline Business demon & $\begin{array}{l}\text { a. Humanist paradigm and is more often used in } \\
\text { economics in achieving good corporate governance } \\
\text { as well as provide additional wealth }\end{array}$ & $\begin{array}{l}\text { a. Political paradigm dominates because in addition } \\
\text { could affect the company's board could also } \\
\text { influence government policy with rents political } \\
\text { relations with the government and other business } \\
\text { demon groups that have the same motivation }\end{array}$ \\
\hline $\begin{array}{l}\text { Board of the } \\
\text { company }\end{array}$ & $\begin{array}{l}\text { a. More humanist paradigm used for fear of being } \\
\text { replaced by a business demon. They are ready to } \\
\text { become a corporate whistleblower so that } \\
\text { inter-company boards arises mutual distrust }\end{array}$ & $\begin{array}{l}\text { a. Economic paradigm can be used because in } \\
\text { addition to the benefit of the board of the } \\
\text { company can also provide long term benefits for } \\
\text { business demon }\end{array}$ \\
\hline
\end{tabular}

Based on the description, the second proposition is the business demon changes the behaviour of the board of the company militaristic manner in accordance with the experience that the company can survive and can generate additional wealth for shareholders on an ongoing basis

\subsection{Requirements Degree level in Corporate Ownership and Business Demon Value Added Management (BDVAM)}

Arthurs and Busenitz (2012) states that the founder of the company has the right to regulate the company's board, but as the company became a public company now company boards as well as the founder of the company should give priority to the interests of shareholders because of the way the company is guaranteed and financed from shareholder's capital.The global financial crisis (McCarthy,Solomon, and Mihalek, 2012) which occurs opened the eyes of the shareholders of the company due to the amount of money lost due to the company's board did the opacity of financial statements so that the information presented to shareholders to be biased so that the decisions taken by the company to be one/not appropriate. In addition 


\section{NI Macrothink}

Business and Economic Research

ISSN 2162-4860

2014, Vol. 4, No. 1

to pressure from the owner to the board of the company making the minority shareholders is a party that suffered huge losses. Therefore (Dummet, 2013), business demon seeking support with institutional shareholders to acquire the right to appoint and dimiss the board while offering the assurance that the company's stock price and performance will increase if allowed to do a resolution board of the company. This is described in more detail in Table 5 .

Table 5. Implications of applying BDVAM due to the direct involvement business demon

\begin{tabular}{|c|c|c|}
\hline Requirement level & $\begin{array}{l}\text { Positive implications of implementing Business } \\
\text { Demon Value Added Management (BDVAM) }\end{array}$ & $\begin{array}{l}\text { Negative implications of implementing } \\
\text { Business Demon Value Added Management } \\
\text { (BDVAM) }\end{array}$ \\
\hline $\begin{array}{l}\text { Oriented long-term } \\
\text { financial performance }\end{array}$ & $\begin{array}{l}\text { The additional funding from business demon to buy } \\
\text { new companies that can add incremental benefits in } \\
\text { the future }\end{array}$ & $\begin{array}{l}\text { Board of the company does not have a financial } \\
\text { motivation to innovate because there are } \\
\text { political interests of the company's business if } \\
\text { the business demon that will increase the value } \\
\text { of the company will be sold }\end{array}$ \\
\hline $\begin{array}{l}\text { Oriented long-term non } \\
\text { financial performance }\end{array}$ & $\begin{array}{l}\text { a. An increase in the company's intellectual } \\
\text { capital not only financial value } \\
\text { b. Increased corporate political responsibility for } \\
\text { the company trusted by governments, } \\
\text { customers in providing the best products and } \\
\text { quality to be used in bulk in the country. } \\
\text { Similar goods banned because the company is } \\
\text { an asset that should be maintained throughout } \\
\text { the state of society }\end{array}$ & $\begin{array}{l}\text { a. The company's reputation be not as good } \\
\text { as the performance of the busssines demon } \\
\text { who likes to acquire stakes big companies }\end{array}$ \\
\hline
\end{tabular}

Based on the description, the third proposition is the stronger ability of the business demon will pay more attention to long-term company performance. Business demon will have the attention on the issues surrounding the stock price and the value of the company. 


\section{$\triangle$ Macrothink}

Business and Economic Research

ISSN 2162-4860

2014, Vol. 4, No. 1

\subsection{The Interest of Political and Business Demon Value Added Management (BDVAM)}

According to Stigler (1971) in the theory of regulatory capture or private interest theory of government, academics suggested that the decision by the public officials can be influenced and distorted by political rent seeking activities undertaken by business demon in a company that does the implementation of BDVAM for increase his/her wealth. Business demon politically desirable to obtain regulatory and exchange for political donations and support voice. Regulation was not created to serve the public interest but to protect the monopoly rents. Increasingly close relationship between business demon in company with the government which is illustrated in Table 6 affect the prospects of the company now and in the future.

Table 6. The relationship between business demon with the government that affect the prospects today and in the future

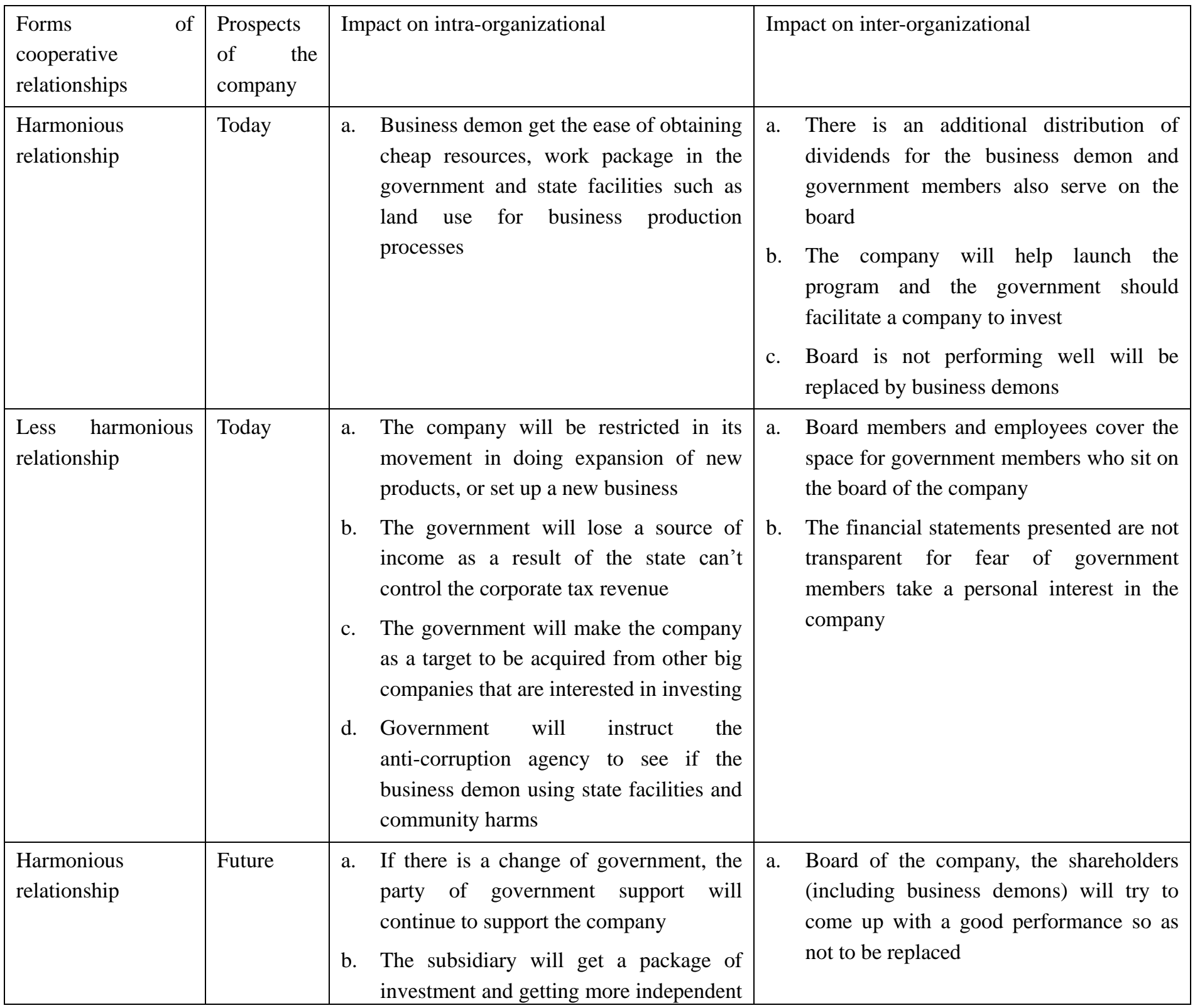




\section{Mll Macrothink Mnstitute}

\begin{tabular}{|l|l|l|l|l|}
\hline & & $\begin{array}{l}\text { than its parent company } \\
\text { c. }\end{array}$ & \\
\hline $\begin{array}{l}\text { Less harmonious } \\
\text { relationship }\end{array}$ & Future & a. $\begin{array}{l}\text { The government will make the company } \\
\text { as a target to be acquired from other big } \\
\text { companies that are interested in investing } \\
\text { b. } \begin{array}{l}\text { There will be a misunderstanding of the } \\
\text { benefits that are required by the } \\
\text { government due to absence of standard } \\
\text { fare for the company as a contribution }\end{array}\end{array}$ & $\begin{array}{l}\text { There will be misunderstandings in } \\
\text { interpreting prospects of the company }\end{array}$ \\
& & \\
\hline
\end{tabular}

Based on the description, the fourth proposition is the ability of business demon in building and implementing a culture sustainable value creation is not always affect the ability of business demon in managing the company's success in making a profit because of the political rents

\subsection{Sustainability Company and Business Demon Value Added Management (BDVAM)}

The global financial crisis (Rose,2010; McCarthy, Solomon, and Mihalek,2012) which occurs in addition to making the financial recession some companies are also several other companies doing massive expansion due to growth of the company in times of crisis, in addition to the government to create a new policy, minority shareholders can cooperate with other shareholders to fulfill certain criteria in ownership include more than one candidate of twenty-five percent of the contested seats. Some of the factors that led to the reason the company in recession because of the corporate governance is not good, the practice of rent-seeking corporate boards because the organizational structure is not shaped single tier or multi tier (Munster and Staal,2012), the inability of the company's board in order to maximize political governance with all stakeholders of the company and its capital structure so that investment decisions have suffered from negative returns. It is different from other big companies that experienced growth due to the structure of share ownership is almost over and the three investors, especially minority shareholders in the company actively participate in the company in determining the company's strategic decisions. This make business demon in investing in the company began to see that the corporate sustainability is important so that the implementation of BDVAM is need to consider internal and external factors cause the company's sustainability (illustrated in Table 7)

Table 7. Internal and External Factors affecting the implementation of BDVAM (Business Demon Value Added Management)

\begin{tabular}{|c|c|c|c|}
\hline Status of Company & $\begin{array}{l}\text { Factors } \\
\text { that } \\
\text { influence }\end{array}$ & $\begin{array}{l}\text { If running the Business Demon Value Added } \\
\text { Management (BDVAM) }\end{array}$ & $\begin{array}{l}\text { If running the Business Demon Value } \\
\text { Destruction Management (BDVDM) }\end{array}$ \\
\hline
\end{tabular}




\section{Macrothink Mnstitute"}

\begin{tabular}{|c|c|c|c|}
\hline & & $\begin{array}{l}\text { c. Boards who have worked very long not } \\
\text { ready if they should be replaced } \\
\text { d. Organizational structure can not affect } \\
\text { the practice of rent-seeking }\end{array}$ & $\begin{array}{l}\text { made to be protected so that the policy can } \\
\text { be acquired by other investors or business } \\
\text { demon who has a motive wants to } \\
\text { destroy/take over the company }\end{array}$ \\
\hline & External & $\begin{array}{l}\text { a. Government urges return for a package } \\
\text { of work that can be found in the } \\
\text { corporate governance projects }\end{array}$ & $\begin{array}{l}\text { a. Investment contract between business } \\
\text { demon and the government violated for } \\
\text { personal gain due to the inability of the } \\
\text { company to establish communication with } \\
\text { the government and pressure from } \\
\text { business demon }\end{array}$ \\
\hline \multirow[t]{2}{*}{ Recession } & Internal & $\begin{array}{l}\text { a. There is tension between the company } \\
\text { and its subsidiaries due to rent-seeking is } \\
\text { performed by the company's board } \\
\text { b. Board of the company that has a good } \\
\text { performance will not be urged to resign } \\
\text { c. The majority shareholder who has a } \\
\text { good motivation not be pressured by } \\
\text { minority shareholders to step down and } \\
\text { relinquish ownership of shares }\end{array}$ & $\begin{array}{l}\text { a. Business demon wants to sit as chairman } \\
\text { of the board and the company could take } \\
\text { the policy and also put those beliefs on } \\
\text { company boards }\end{array}$ \\
\hline & External & $\begin{array}{l}\text { a. Government and potential investors will } \\
\text { offer grants for the company because } \\
\text { there is a policy that protects the } \\
\text { company if the recession } \\
\text { b. The assets of the company that makes } \\
\text { the performance of the company can be } \\
\text { sold quickly down to be convered into } \\
\text { cash because of the proximity of the } \\
\text { business demon with investors }\end{array}$ & $\begin{array}{l}\text { a. The assets of the company and several } \\
\text { subsidiaries that are not productive } \\
\text { immediately sold to the government or } \\
\text { large corporate investors }\end{array}$ \\
\hline
\end{tabular}

Based on the description, the fifth proposition is the larger companies with many subsidiaries, the easier the implementation of Business Demon Value Added Management (BDVAM) by business demon, because business demon can do combination of strategy implementation Business Demon Value Destruction Management (BDVDM)

\section{Conclusions and Recommendations.}

\subsection{Conclusions}

The concept of BDVAM is an easy concept to understand but not all companies can do because the board is replaced with the fear of new people/independent consultant brought in by business demons and other shareholders acquired its stake fear business demon. Typically, business demon inside launch the action will submit a proposal to the other shareholders, and if it is important then to be held General Meeting of Shareholders Extraordinary. Business demon capabilities in influencing the media and government to make corporate boards that have performed poorly in order to seek to advance still be sitting in the office. They will be a whistleblower for the business demon to find out if the board of other companies or existing 
shareholders who do monopoly rents for personal gain.

This concept also adds value for companies indirectly because the attitude of active business demon can affect policy change, but also must consider whether there are incentives that the government requested that in the future could affect the sustainability of the business and the company's reputation in the community. Addition of a few other events, the presence of business demon in value through direct involvement using the concept of Business Demon Value Destruction Management (BDVDM) which agreed with the company's board to rebel against the majority shareholder. Business demon trying to create a bubble stock prices by distorting the company's policies and decisions. This is because business demon invest in the stock ownership of the other big companies either similar or not, it resulted when business demon need funds quickly then it could force companies to sell its assets in order to be able to make a profit. Addition of several studies on BDVAM suggest to the company and shareholders of the five conditions that could be a condition of success implementing BDVAM namely: (1) business demon commitment to press the company's board with the implementation of BDVAM according to which best suits the desire to direct involvement in the company is very desirable, (2) business demon changes the behavior of the board in accordance with the company's militaristic experience so that the company can survive and can generate additional wealth for shareholders on an ongoing basis, (3) the stronger the ability of business demon will pay more attention to long-term company performance, business demon will have the attention on the issues surrounding the stock price and the value of the company, (4) the ability of business demon in building and implementing a culture of sustainable value creation is not always affect the ability of business demon in the company's success in managing the making a profit because of the political rents, (5) the larger companies with many subsidiaries, the easier the implementation of BDVAM by business demon because business demon can do a combination of strategy implementation of Business Demon Value Destruction Management (BDVDM).

\subsection{Recommendation for Further Research}

The purpose of this paper is to derive propositions about the reasons for the success and failure of implementation of BDVAM. Based on the existing literature, there are five factors that must be considered in implementing BDVAM. However, the proposition in this paper did not answer all of the phenomena associated BDVAM because BDVAM is a fairly complex issue and companies globally. The following cause BDVAM topics can still be extended in subsequent research, namely: (1) the countries of the ASEAN community 2015 that has the highest level of corruption indicator or range of countries categorized as fragile five (Brazil, India, South Africa, Turkey, and Indonesia), (2) the range of industries associated with the government, (3) the level of experience in the investment business demon stock ownership, (4) the grade levels in the world's top ten richest people in the capital invested in the form of company stock ownership.

\subsection{Recommendation for Corporate Management}

From proposition of this study is expected to be a guide for the company's board to be careful in managing the company and remain always maintain good relations with business demon 
because it does BDVAM implementation could be more damaging is the company in the long run. In addition the company's board still must perform proactive coordination with the government, especially with the commercial court did not make the opacity of financial statements that may form political responsibility of good governance.

\section{References}

Adegbite, Emmanuel, Amaeshi, Kenneth, Amao, \& Olufemi. (2011). The Politics of Shareholder Activism in Nigeria. Journal Business Ethics, 105, 389-402.

Agle, B. R., Mitchell, R. K., \& Sonnenfeld, J. A. (1999). Who matters to CEOs? An investigation of stakeholder attributes and salience, corporate performance, and CEO values. Academy of Management Journal, 42(3), 507-525. http://dx.doi.org/10.2307/256973

Ameer, R., Othman, R., \& Mahzan, N. (2012). Information asymmetry and regulatory shortcomings in profit sharing investment accounts. International Journal of Islamic and Middle Eastern Finance and Management, 5(4), 371-387. http://dx.doi.org/10.1108/17538391211282854

Anderson, S. W., \& Dekker, H. C. (2009). Strategic Cost Management in Supply Chains,Part 1: Structural Cost Management. Accounting Horizons, 23(1), 289-305. http://dx.doi.org/10.2308/acch.2009.23.3.289

Anonymous. (2007). Business: In the locust position, Shareholder activism in Japan. The Economist, 383, 80.

Anonymous. (2013). Shareholders at the gates; Corporate governance. The Economist, 406, $8826,63-64$

Anonymous. (2014). How activist shareholders turned from villains into heroes: The Economist explains. The Economist.

Aram, John D. (1989). Attitudes and behaviors of informal investors toward early-stage investing, Technology-based ventures, and co-investors. Journal of Business Venturing, 4(5), 333-347. http://dx.doi.org/10.1016/0883-9026(89)90005-0

Ardichvili, A., R. N. Cardozo, K. Tune, \& J. Reinach. (2002). The role of angel investors in the assembly of non-financial resources to new ventures: Conceptual frameworks and empirical evidence. Journal of Enterprising Culture, 10(1), 39-65. http://dx.doi.org/10.1142/S021849580200013X

Arthurs, Jonathan. D., Busenitz, \& Lowell. W.(2003). The Boundaries and Limitations of Agency Theory and Stewardship Theory in the Venture Capitalists/Entrepreneur Relationship. Entrepreneurship Theory and Practice Journal, Bayor University. http://dx.doi.org/10.1046/j.1540-6520.2003.00036.x

Barac, Zeljana Aljinovic, Markota, Ljerka, Belak, \& Vinko. (2013). Business Value Added Management and Company's Financial Performance. The Business Review, Cambridge, 21(1), 237-243 
Barber, B. M. (2006). Monitoring the monitor: Evaluating CalPERS 'shareholder activism. Journal of Investing, 16, 66-80. http://dx.doi.org/10.3905/joi.2007.698965 http://dx.doi.org/10.3905/joi.2007.698965

Becker, B., \& Gerhart, B. (1996). The impact of human resource management on organizational performance: progress and prospects. Academy of Management Journal, 39(4), 770-801. http://dx.doi.org/10.2307/256712

Beckhard, R., \& Dyer, G. W. (1983). Managing continuing in the family owned Organizational Dynamic, 11, 5-12. http://dx.doi.org/10.1016/0090-2616(83)90022-0

Bates, Steve. (2009). Report: Prepare For Increased Shareholder Activism. HR Magazine, 54(6), 32.

Becht, M., Franks, J., Mayer, C., \& Rossi, S. (2010). Returns to shareholder activism: Evidence from a clinical study of Hermes UK Focus Fund. Review of Financial Studies, 22, 3093-3129. http://dx.doi.org/10.1093/rfs/hhn054

Belak, V; Aljinovic Barac, Z., \& Tadic, I (2009). Recognition and measurement of human capital expenditures - impacts on company's performance measurement. International Journal of Economics and Business Research, 1, 2, 252-262. http://dx.doi.org/10.1504/IJEBR.2009.024023

Benjamin, Gerald A., \& Magulis, Joel (2001). The angel investor's handbook. Princeton, NJ: Bloomberg Press.

Bennett, Bruce C.(2008). Reflections on Indenture Remedies and Investor Protection. Insights; The Corporate \& Securities Law Advisor, 22(2), 11-22.

Benoit, David. (2014). New Push to Throw Assets Overboard. Easter Edition, C.1.

Benoit, David., Chung, Juliet. (2014). Activist Presses Tribune To Sell Assets. Eastern Edition, 24, B1.

Berglas, Steven. (1998). The entrepreneurial avenger. ABI/INFORM Research,20 (11),35.

Bezemer, P.-J., Peij, S. C., Maassen, G. F., \& Van Halder, H. (2010). The Changing Role of the Supervisory Board Chairman: The Case of the Netherlands (1997-2007). Journal of Management and Governance.

Boselie, P. Dietz, G., Boon, C. (2005). Commonalities and contradictions in HRM and performance research. Human Resource Management Journal, 15(3), 67-94. http://dx.doi.org/10.1111/j.1748-8583.2005.tb00154.x

Brav, A., Jiang, W., Partnoy, F., \& Thomas, R. (2008). Hedge fund activism, corporate governance, and firm performance. Journal of Finance, 63, 1729-1775. http://dx.doi.org/10.1111/j.1540-6261.2008.01373.x

Brophy, David J., \& Shulman, Joel M. (1992). A finance perspective on entrepreneurship research. Entrepreneurship: Theory and Practice, 16, 61-71. 
Budsaratragoon, Pornanong, Lhaopadchan, Suntharee, \& Hillier, David. (2010). Institutional Shareholder Activism and Limited Investor Attention. Review of Behavioral Finance, 2, 106-124. http://dx.doi.org/10.1002/rbf.12

Burr, Barry B. (2012). Managers increasing activism on governance-but quitetly. Pensions \& Investments, 40(6).

Bhattacharya, S. (1979). Imperfect Information, Dividend Policy and the Bird-in-Hand fallacy. The Bell Journal of Economics, 10, 259-270. http://dx.doi.org/10.2307/3003330

Burke, E. M. (1999). Corporate community relations: The principle of the neighbor of choice. Westwood, CT: Praeger.

Burton, M. D., \& O'Reilly, C. (2000). The impact of high commitment values and practices on technology slart-ups (Working Paper). Cambridge, MA: MIT Sloan School of Management.

Caton, Gary L., Goh, Jeremy, Donaldson, Jeffrey. (2001). The effectiveness of Institutional activism. Financial Analysts Journal, 57(4), 21-26. http://dx.doi.org/10.2469/faj.v57.n4.2462

Cheffins, Brian R, Armour, John. (2011). The Past, Present, and Future of Shareholder Activism by Hedge Funds. Journal of Corporation Law, 37(1),51-103.

Cheng, C. S. A., Huang, H. H., Li, Y., \& Lobo, G. (2010). Institutional monitoring through shareholder litigation. Journal of Financial Economics, 95,345-383.

Cloke., K., Goldsmith, J. (2002). The End of Management, Jossey-Bass, San Francisco, CA.

Cockerill, Chris. (2002). Devil or Angel? Euromoney 400, 30-33.

Corlette, J. A. (1989). The "modified vendetta sanction" as method of corporate collective punishment. Journal of Business Ethics, 8, 937-942. http://dx.doi.org/10.1007/BF00383428

Crispin, S. W. (2002). Political connections. Far Eastern Economic Review, 165(21), 33.

Curtis, Abraham. (2003). Angel of Africa. New Scientists, 177. 2385, 50-53.

Davidson, W. N., Worrell, D. L., \& El-Jelly, A. (1995). Influencing managers to change unpopular corporate behavior through boycotts and divestitures: A slock market test. Business \& Society, 34, 171-196. http://dx.doi.org/10.1177/000765039503400204

Davis, B. (2001). Chairman's deep political conncections run silent. Wall Street Journal Eastern Edition, 238, A10.

DeAngelo, H., \& L. DeAngelo. (1989). Proxy Contests and the Governance of Publicly Held Corporations. Journal of Law and Economics, 23,29-59.

Del Guercio, D., \& Hawkins, J. (1999). The motivation and impact of pension fund activism. Journal of Financial Economics, $293-340$. http://dx.doi.org/10.1016/S0304-405X(99)00011-2

Del Guercio, D., Seery, L., \& Woidtke, T. (2008). Do boards pay attention when institutional 
investor activists “just vote no"?. Journal of Financial Economics, 90, 84-103. http://dx.doi.org/10.1016/j.jfineco.2008.01.002

Denis, D. J. (2004). Entrepreneurial Finance: An Overview of the Issues and Evidence. Journal of Corporate Finance, $\quad 10, \quad 301-326$. http://dx.doi.org/10.1016/S0929-1199(03)00059-2

Dummett, Ben (2013). Activist Shareholder Wants Board Seats At Canada's Sherritt; Key Shareholder Dissapointed With Stock Price and Company's Operational Performance. Wall Street Journal (Online), n/a.

Durnev, Art, Randall Morck, \& dan Bernard Yeung, (2004), Value-enhancing capital budgeting and firm specific stock return variation, Journal of Finance, 59,65-105. http://dx.doi.org/10.1111/j.1540-6261.2004.00627.x

Duxbury, Linda, Haines, George, \& Riding, Allan (1996). A personality profile of Canadian informal investors. Journal of Small Business Management, 34(2), 44-55.

Dyer, W. G., Jr., \& Sanchez, M. (1998). Current state of family business theory and practice as reflected in Family Business Review, 1998-1997, Family Business Review, 11,287-296. http://dx.doi.org/10.1111/j.1741-6248.1998.00287.x

Eisenhardt, K. (1989). Agency theory: An assessment and review. Academy of Management Review,14(1),57-74

English, P. C., II, Smythe, T. I., \& McNeil, C. R. (2004). The "CalPERS effect" revisited. Journal of Corporate Finance, 10,157-174. http://dx.doi.org/10.1016/S0929-1199(03)00020-8

Ertimur, Y., Ferri, F., \& Stubben, S. R. (2010). Board of directors' responsiveness to shareholders: Evidence from shareholder proposals. Journal of Corporate Finance, 16, 53-72. http://dx.doi.org/10.1016/j.jcorpfin.2009.07.005

Faccio, Mara. (2006). Politically connected firms. American Economic Review, 96, 369-386. http://dx.doi.org/10.1257/000282806776157704

Faccio, Mara, John J. McConnell, \& Ronald W. Masulis. (2006). Political connections and corporate bailouts. Journal of Finance, 61, 2597-2635.

Fama, E. F., \& Miller, M. H. (1972). The theory of finance. New York: Holt, Rinehart and Winston.

Feldman, S. J., Soyka, P. A., \& Ameer, P. G. (1997). Does improving a firm's environmental management system and environmental performance result in a higher stock price? Journal of Investing, 6(4), 87-97. http://dx.doi.org/10.3905/joi.1997.87

Fernandez, P. (2012). Revenue Disruption: Game-Changing Sales and Marketing Strategies to Accelerate Growth. Hoboken, New Jersey:John Wiley \& Sons.

Filbeck, Greg, Leee Sharon. (2000). Financial Practices in Family Business. Family Business 
Review, 13(3), 201-216. http://dx.doi.org/10.1111/j.1741-6248.2000.00201.x

Filippello, A Nicholas. (1993). Giving investor the facts. Chemical Business, 15.

Fisman, Raymond. (2001). Estimating the value of political conncetions. American Economic Review, 91, 1095-1102. http://dx.doi.org/10.1257/aer.91.4.1095

Foss, N., Foss, K. and Vazquez-Vicente, X.H. (2003).'Tying the manager's hands': how firms can make credible commitments that make opportunistic managerial intervention less likely, DRUID Working Paper 2003-10, Copenhagen Business School.

Freear, John, \& Wetzel, William (1989). Equity capital for entrepreneurs. In Frontiers of Entrepreneurship Research 1989. Babson Park, Mass.: Babson College.

Freear, John, Sohl, Jeffrey, \& Wetzel, William (1990). Raising venture capital: entrepreneurs' view of the process. In Frontiers of Entrepreneurship Research 1990. Babson Park, Mass.: Babson College.

Freear, John, Sohl, Jeffrey, \& Wetzel, William (1991). Raising venture capital to finance growth. In Frontiers of Entrepreneurship Research 1991. Babson Park, Mass.: Babson College.

Freear, John, Sohl, Jeffrey, \& Wetzel, William (1992). The investment attitudes, behavior and characteristics of high net worth individuals. In Frontiers of Entrepreneurship Research 1992. Babson Park, Mass.: Babson College.

Freear, John, Sohl, Jeffrey, \& Wetzel, William (1994). Angels and non-angels: Are there differences? Journal of Business Venturing, 9(2), 109-123. http://dx.doi.org/10.1016/0883-9026(94)90004-3

Freear, John, Sohl, Jeffrey, \& Wetzel, William (1995). Angels: personal investors in the venture capital market. Entrepreneurship \& Regional Development, 7, 85-94. http://dx.doi.org/10.1080/08985629500000005

Freear, John, Sohl, Jeffrey, \& Wetzel, William (1996). The informal venture capital market: milestones passed and the road ahead. Paper presented at the fourth State of the Art in Entrepreneurship Research Conference, May 9-11, 1996.

Freear, J., J. E. Sohl, and W. E. Wetzel. (1997). The informal venture capital market: Milestones passed and the road ahead. In Entrepreneurship 2000, ed. D.L. Sexton and R.W. Smilor, 47-69. Chicago: Upstart Publishing Company.

French, P. (1984). Collective and Corporate Responsibility. Columbia University Press, New York.

Friedman, Milton., Anna, Jacobson. (1963). A Monetary History of the United States, 1867-1960, Princeton: Princeton University Press.

Frooman, J. (1999). Stakeholder influence strategies. Academy of Management Review, 24(2), 191-205. 


\section{1) Macrothink}

Business and Economic Research ISSN 2162-4860 2014, Vol. 4, No. 1

Gaston, R. J. (1989). The scale of informal venture capital markets. Small Business Economics, 1, 223-230. http://dx.doi.org/10.1007/BF00401859

Gee, Erin Preston. (2002). Three strategies to improve your bottom line. Healthcare Executive, 17(4), 8-13.

Gibson, K. (1995). Fictitious Persons and Real Responsibilities. Journal of Business Ethics,14(9), 761-767. http://dx.doi.org/10.1007/BF00872329

Gillan, S. L., \&Starks, L. T. (2000). Corporate governance proposals and shareholder activism: The role of institutional investors. Journal of Financial Economics, 57, 275-305. http://dx.doi.org/10.1016/S0304-405X(00)00058-1

Gombola, Michael J, Feng-Ying, Liu (1999). The signaling power of specially designated dividends. Journal of Financial and Quantitative Analysis, 34(3), 409-424. http://dx.doi.org/10.2307/2676266

Goodpaster, K. (1983). The concept of Corporate Responsibility. Journal of Business Ethics, 2(1), 122. http://dx.doi.org/10.1007/BF00382708

Gordon, L., \& J. Pound, (1993). Information, Ownership Structure, and Shareholder Voting: Evidence from Shareholder-Sponsored Corporate Governance Proposals. Journal of Finance, 48(2), 697-718. http://dx.doi.org/10.1111/j.1540-6261.1993.tb04734.x

Graves, S. B., Rehbein, K. A., \& Waddock, S. A. (2001). Fad and fashion's shareholder activism: The landscape of shareholder resolutions, 1988-1998. Business and Society Review, 106(4), 293-315. http://dx.doi.org/10.1111/0045-3609.00117

Gray, John. (2003). Shareholder No. 1. Canadian Business, 76, 14.

Greenwood, R., \& Schor, M. (2009). Investor activism and takeovers. Journal of Financial Economics, 92, 362-375. http://dx.doi.org/10.1016/j.jfineco.2008.05.005

Gunawan, J., Scheela, W., Wessiani, N. A., \& Luthfiyah, M. (2011). Promoting entrepreneurship research and education about business angels in Indonesia. A paper presented at the UNESCO-APIED International Conference, Jakarta, Indonesia, December, 6-8.

Gul, Ferdinan A., Jeong-Bon Kim, \& dan Annie A. Qiu, (2010), ownership concentration, foreign shareholding, audit quality, and stock price synchronicity: evidence from China, Journal of Finance, 95, 425-442.

Gupta, A. K., \& Govindarajan, V. (1991). 'Knowledge flows and the structure of control within multinational firms', Academy of Management Review 16(4), 768-792. http://dx.doi.org/10.1002/(SICI)1097-0266(200004)21:4<473::AID-SMJ84>3.0.CO;2-I

Gupta, A. K., \& Govindarajan, V. (2000). 'Knowledge flows within multinational corporations', Strategic Management Journal 21(4), 473-496.

Habib, M., \& Zurawicki, L. (2002). Corruption and Foreign Direct Investment. Journal of 
International Business Studies, 33, 291-308. http://dx.doi.org/10.1057/palgrave.jibs.8491017

Habib, M., \& Zurawicki, L. (2005). Corruption and Its Effect on Trade and FDI, in: Global Corruption Report 2005, Berlin: Transparency International, 305-307.

Harr, N. E., J. Starr, \& I. C. MacMillan. (1988). Informal risk capital investors: Investment patterns on the east coast of the USA. Journal of Business Venturing, 3, 11-29. http://dx.doi.org/10.1016/0883-9026(88)90027-4

Harrison, Richard T., Dibben, Mark R., \& Mason, Colin M. (1997). The role of trust in the informal investor's decision: an exploratory analysis. Entrepreneurship: Theory and Practice, 21(4), 63-81.

Hasan, M. (2013). Sustainable Supply Chain Management Practices and Operational Performance. American Journal of Industrial and Business Management, 3, 42-48. http://dx.doi.org/10.4236/ajibm.2013.31006

Hill, Brian E., \& Power, Dee. (2002). Attracting Capital From Angels. New York: John Wiley \& Sons.

Hillman, A., \& Keim, G. D. (2001). Shareholder value, stakeholder management, and social issues: What's the bottom line? Strategic Management Journal, 22(2), 125-139. http://dx.doi.org/10.1002/1097-0266(200101)22:2<125::AID-SMJ150>3.0.CO;2-H

Hindle, K., \& Lee, L. (2002). An exploratory investigation of informal venture capitalists in Singapore. Venture Capital, 4(2), 169-181. http://dx.doi.org/10.1080/13691060110091255

Hindle, K., \& R. Wenban. (1999).Australia's informal venture capitalists: An exploratory profile. Venture Capital, 1(2), 169-186. http://dx.doi.org/10.1080/136910699295956

Hoontrakul, Pongsak (2001). Angel Financing. A presentation at 123 Forum.

Hoskin, K., \& Macve, R. (1990). Understanding modern management. University of Wales Business and Economics Review, 5, 17-23.

Huang, S. Y., Hung, Y. C., Lin, C. C., \& Tang, LJ. (2009): The effects of innovative capacity and capital expenditures on financial performance, International Journal of Innovation and Learning, 6(3), 323-341. http://dx.doi.org/10.1504/IJIL.2009.023294

Hunt, A.R. (2002). A scandal centerpiece: Enron's political connections. Wall Street Journal Eastern Edition, 239, A15.

Huselid, M. A. (1995). The impact of human resource management practices on turnover, productivity, and corporate financial performance. Academy of Management Journal, 38, 647-672. http://dx.doi.org/10.2307/256741

Huselid, M. A., Jackson, S. E., \& Schuler, R. S. (1997). Technical and strategic human resource management effectiveness as determinants of firm performance. Academy of Management Journal, 40(1), 171-188. http://dx.doi.org/10.2307/257025

Husnan, Suad. (2001). Indonesia, in Corporate Governance and Finance in East Asia, Asian Development Bank. 
Hutton, Amy P., Alan J. Marcus, \& Hassan Tehranian. (2009). Opaque financial reports, R2, and crash risk. Journal of Financial Economists, 94, 67-86. http://dx.doi.org/10.1016/j.jfineco.2008.10.003

Ibrahim, Darian. (2008). The (Not So) Puzzling Behavior of Angel Investor. Vanderbilt Law Review, 61(5), 1403.

Ichniowski, C., \& Shaw, K. ( 1999). The effects of human resource management systems on economic performance: An international comparison of US and Japanese plants. Management Science, 45(5), 704-721. http://dx.doi.org/10.1287/mnsc.45.5.704

Jin, Li, \& Stewart C. Myers. (2006). $\mathrm{R}^{2}$ around the world: new theory and new tests. Journal of Financial Economics, 67, 351-382

Jones, N., H, Jones, L. Steer, \& A. Datta. (2009a). Improving Impact Evaluation Production and Use. Working Paper 300.

Kaplansky, G., \& Levy H. (2010). Sentiment and stock prices: The case of aviation disasters. Journal of Financial Economics, 95, 174-201. http://dx.doi.org/10.1016/j.jfineco.2009.10.002

Kapner., D. A. (2003). Alcohol and other drugs on campus: The scope of the problem (The Higher Education Center for Alcohol and other Drug Prevention Infofacts). Washington, D.C, The U.S. Department of Education

Kelly, L. M., Athanassious, N., Crittenden, W. F. (2000). Founder centrality and the strategic behavior in the family-owned firm. Entrepreneurship Theory \& Practices, 25(2), 27-42.

Kelly, P. (2000). Private investors and entrepreneurs: How context shapes their relationship. Doctoral Diss., Foundation for Entrepreneurial Management London Business School, London.

Kelly, P., \& Hay, M. (2000). Deal Makers: Reputation Attracts Quality. Venture Capital, 2, 183-202. http://dx.doi.org/10.1080/13691060050135073

Kelly, Ross. (2013). Shareholder Activism Rises Down Under; The Most Recent Target is Seen as a Test of Activism Efficacy for Larger Companies. Wall Street Journal. [Online]Available: online.wsj.com.

Kim, W., Kim, W., \& Kwon, K.S. (2009). Value of outside blockholder activism: Evidence from the switchers. Journal of Corporate Finance, 15, 505-522. http://dx.doi.org/10.1016/j.jcorpfin.2009.04.002

Klein, A., \& Zur, E. (2009). Entrepreneurial shareholder activism: Hedge funds and other $\begin{array}{llll}\text { private investors. Journal of } & \text { Finance, 64, }\end{array}$ http://dx.doi.org/10.1111/j.1540-6261.2008.01432.x

Korhonen, Andreia. (2009). Business Angels in Brazil: Starting up a venture to unite Brazilian entrepreneurs and foreign investors. Final Thesis Report, Tampereen Ammattikorekeakoulu, University of Applied Sciences, 1-38. 
Kreuger, A. (1974). The political economy of the rent seeking society. American Economic Review, 64, 291-303.

Kutsuna, K., \& N. Harada. (2004).Small business owner-managers as latent informal investors in Japan: Evidence from a country with a bank-based financial system. Venture Capital, 6(4), 283-311. http://dx.doi.org/10.1080/1369106042000282574

Landstrom, H. (1992). The relationship between private investors and small firms: An agency theory approach. Entrepreneurship and Regional Development, 4, 193-223. http://dx.doi.org/10.1080/08985629200000012

Lantz, J., \& Sahut, J. (2009).Active Financial Intermediation and Market Efficiency: The Case of Fast-Growing Firms Financed by Venture Capitalists.International Journal of Business, 4, 321-339.

Lantz, J., Montandrau, Sophie, \& Sahut, J. (2010). Activism of Institutional Investors, Corporate Governance Alerts and Financial Performance. International Journal of Business, 15(2), 221-240.

Lee, Brian., Seo, \& Duk Soo. (2009). Reforms in the Korean Financial Reporting Systems and Earnings Quality. Asia-Pacific Financial Markets Research, 17, 51-61, Springer.

Lee, D. W., \& Park, K. S. (2009). Does institutional activism increase shareholder wealth? Evidence from spillovers on non-target companies. Journal of Corporate Finance, 15, 488-504. http://dx.doi.org/10.1016/j.jcorpfin.2009.03.002

Lin, Dan; Lin, Lu. (2014). The Interplay between Director Compensation and CEO Compensation. The International Journal of Business and Finance Research, 8(2), 11-26.

Linde, Lucinda, \& Prasad, Alok (2000). Venture Support Systems Project: Angel investors. Unpublished manuscript, MIT Entrepreneurship Center.

Lipton, Martin. (2007). Shareholder Activism and the 'Eclipse of The Public Corporation'. Insights; The Corporate \& Securities Law Advisor, 21(2),36-40.

Lublin, Joann S. (2011). Directors Must Decide Whether to Move to Conventional Form of Governance. Wall Street Journal, Eastern Edition, New York.

Madill, J. J., G. H. Haines, \& A. L. Riding. (2005). The role of angels in technology SMEs: A link to venture capital. Venture Capital, 7(2), 107-129. http://dx.doi.org/10.1080/1369106042000316341

MacGregor, James, Campbell, Ian. (2008). Dealing with investor activism: Investors seek cash returns from pushing your buttons-There are things you can do to prepare for an attack. International Journal of Disclosure and Governance, 5(1), 23-35. http://dx.doi.org/10.1057/palgrave.jdg.2050070

Manzoor, Amir. (2013). Hermitage Fund: Shareholder Activism and Corporate Governance. Journal of Business Studies Quarterly,4(4), 26-46. 
Mason, C. M., \& R. T. Harrison. (1994). Informal venture capital in the UK. In Finance and the small firm, ed. A. Hughes and D. J. Storey. 64-111. London: Routledge.

Mason, C., R.T. Harrison, \& J. Chaloner.(1991). Informal risk capital in the UK: A study of investor characteristics, investment preferences and investment decision-making. Venture Finance Research Project, Working Paper No. 2, University of Southampton (UK) and University of Ulster at Jordanstown (Northern Ireland).

Maula, Markku, Autio, Erkko, \& Arenius, Pia (2003). What drives micro-angel investments? A large sample study of the factors explaining micro-angel investments. Working Paper Series 91-WP-2003-001. Espoo, Finland: Helsinki Univeristy of Technology.

McCarthy, Marry, Solomon, Paul, Mihalek, Paul. (2012). Financial Crisis During 2007 and 2008: Efficient Markets or Human Behavior?. Journal of Applied Business Research, 28(6), 1275-1281

Miller, M., \& K. Rock. (1985). Dividend Policy under Asymmetric Information, Journal of Finance, 40, 1031-1051. http://dx.doi.org/10.1111/j.1540-6261.1985.tb02362.x

Mobarak, Ahmed Mushfiq and Denni Puspa Purbasari. (2005). Political trade protection in developing countries: firm level evidence from Indonesia, Working Paper, University of Colorado at Boulder.

Morck, Randall, \& Bernard Yeung. (2004). Family control and te rent seeking society. Entrepreneurship Theory and Practice, 28, 391-409. http://dx.doi.org/10.1111/j.1540-6520.2004.00053.x

Moyer., R. Charles, Rao, P. Ramesh., Regnard, Jean Francois. (1996). Signalling and Mimicry: The Evidence from Firim Goal Definition. Managerial Finance, 22(8), 3-17. http://dx.doi.org/10.1108/eb018573

Munck, C., Saublens, C. (2005). Introduction to Business Angels and Business Angels Network Activities in Europe. European Business Angel Network.

Munster, Johannes., Staal, Klaas. (2012). How organizationa structure can reduce rent-seeking. Public Choice, 150(3-4), 579-594. http://dx.doi.org/10.1007/s11127-010-9717-3

Nelson, J. M. (2006). The "CalPERS effect" revisited again. Journal of Corporate Finance, 12, 187-213. http://dx.doi.org/10.1016/j.jcorpfin.2005.07.002

Nelson, Jacqueline. (2012). A New Wave of Activism. Canadian Business,85(3), 14.

Miles, R. H. (1987). Managing the corporate social environment: A grounded theory. Englewood Cliffs, NJ: Prentice Hall.

Myles, Danielle. (2011). How shareholder activism has changed. International Financial Law Review,n/a.

O'Reilly, C., \& Pfeffer, J. (2000). Hidden value: How great companies achieve extraordinary results with ordinary people. Boston: Harvard Business School Press. 
Paul, K., \& Lydenberg, S. D. (1992). Applications of corporate social monitoring systems. Journal of Business Ethics, 11, 1-10. http://dx.doi.org/10.1007/BF00871986

Paul, S., G. Whittam, \& J. B. Johnston. (2003). The operation of the informal venture capital market in Scotland. Venture Capital, 5(4), 313-335. http://dx.doi.org/10.1080/1369106032000141931

Pfeffer, J., \& Veiga, J. F. (1999). Putting people first for organizational success. Academy of Management Executive, 13(2), 37-48.

Piotroski, J. D., T. J. Wong, \& T. Zhang. (2010). Political incentives to suppress negative financial information: evidence from state-controlled Chinese firms. Working Paper.

Piontkowski, J. O.; Hoffian, ?; Lachmann, M.; Schuchardt, L. D. (2012): Determinants of the Implementation and Long-Term Use of Interorganizational Cost Management Tools - An Experimental Investigation. In Davila, ?.; Epstein, M.J.; Manzoni, J.F. (ed.) Performance Measurement and Management Control: Global Issues (Studies in Managerial and Financial Accounting, Volume 25), Emerald Group Publishing Limited, 223-246

Politis Diamanto.(2008).Business angels and value added: what do we know and where do we go?. Journal of Venture Capital, 10, 127-147. http://dx.doi.org/10.1080/13691060801946147

Purwoto, Lukas. (2011). Pengaruh koneksi politis, kepemilikan pemerintah, dan keburaman laporan keuangan terhadap kesinkronan dan risiko crash harga saham, Disertasi, Universitas Gadjah Mada, Jakarta.

Rahardjo, Hartono, Idrus, M. S., Hadiwidjojo, Djumilah, \& Aisjah, Siti. (2013).Factors that Determines the Success of Corporate Sustainability Management. Journal of Management Research, 5, 2

Ranken, N. (1987). Corporations as Persons: Objectives to Goodpaster's "Principle of Moral Projection". Journal of Business Ethics, 6(8), 633-637. http://dx.doi.org/10.1007/BF00705779

Rassoul Y.(2006).Behavioral Finance and Entrepreneurial Finance, The Journal of Entrepreneurial Finance and Business Ventures, 11, 1-3.

Ragnar, Andreas Severinsen, Marius, Monsen Ragnoy, Lars, Dybvik. (2012). Business Angels \& Non-Financial Contributions. Journal of NTNU School of Entrepreneurship, 1-134.

Rédis, J. (2009). The Impact of Business Model Characteristics on IT Firms' Performance. International Journal of Business, 14, 291-307.

Rehbein, Kathleen, Waddock, Sandra, Graves, Samuel B. (2004). Understanding Shareholder Activism: Which Corporations Are Targeted?. Business and Society, 43(3), 239-267. http://dx.doi.org/10.1177/0007650304266869

Reitan, B., and R. Sorheim.(2000). The informal venture capital market in Norway: Investor characteristics, behavior and investment preferences. Venture Capital, 2(2), 129-141. 
http://dx.doi.org/10.1080/136910600295747

Riding, A., \& Short, D. (1987). On the estimation of the investment potential of informal investors: a capture-recapture approach. Journal of Small Business and Entrepreneurship, 5(4), 26-40.

Rochlin, S. A., \& Christoffer, B. (2000). Making the business case: Determining the value of corporate community involvement. Chestnut Hill, MA: Boston College Center for Corporate Community Relations.

Romano, R, (2001). Less is More: Making Institutional Investor Activism a Valuable Mechanism of Corporate Governance. Yale Journal of Regulation, 18,174-251.

Rowley, T. J., \& Moldoveanu, M. (2003). When will stakeholders groups act? An interest and identity based model of stakeholder group mobilization. Academy of Management Review, 28(2), 204-219.

Rose, Paul (2010). Common Agency and The Public Corporation. Vanderbilt Law Review, 63(5)-1355-1417.

Salzman, Avi. (2013). How to Profit From Today's Shareholder Activism. Barron's, 93, 25-26,28.

Scheela, William and Isidro,Edmundo. (2012).Business Angel Investing in Emerging Economies: Policy Implications for Southeast Asia. Kauffman Foundation's International Research and Policy Roubtable.

Shleifer, Andrei dan Robert W. Vishny, 1994, Politicians and firms, Quarterly Journal of Economics 109,995-1025.

Solh, M. (2000).Fonds de pension et politique d'investissement a long terme des enterprises. Doctorate Thesis in Management Science, University of Paris E Naterre..

Sohl, Jeffrey E. (2004). The angel investor market in 2003: The angel market rebounds, but a troublesome post seed funding gap deepens.

Sonfield, Matthew C., Lussier, Robert N. (2004). First-, Second-, and Third-Generation Family Firms: A Comparison. Family Business Review, 17(3), 189. http://dx.doi.org/10.1111/j.1741-6248.2004.00013.x

Sørheim, R., and H. Landström (2001). "Informal Investors-A Categorisation, with Policy Implications," Entrepreneurship and Regional Development 13, 351-370. http://dx.doi.org/10.1080/08985620110067511

Sorheim, Roger. (2005). Business angels as facilitators for further finance: an exploratory study. Journal of Small Business and Enterprise Development, 12(2), 178-191. http://dx.doi.org/10.1108/14626000510594593

Stedler, H.R., and H.H. Peters. (2003). Business angels in Germany: An empirical study. Venture Capital, 5 (3), 296-276. http://dx.doi.org/10.1080/1369106032000126596 
Stigler, George J., (1971) The theory of economic regulation, Bell Journal of Economics and Management Science, 2, 3-21. http://dx.doi.org/10.2307/3003160

Sullivan, Mary Kay (1991). Entrepreneurs as informal investors: Are there distinguishing characteristics? In Frontiers of Entrepreneurship 1991. Babson Park, Mass.: Babson College.

Sullivan, Mary Kay, \& Miller, Alex (1990). Applying theory of finance to informal risk capital research: promise and problems. In Frontiers of Entrepreneurship 1990. Babson Park, Mass.: Babson College.

Sullivan, Mary Kay, \& Miller, Alex (1996). Segmenting the informal venture capital market: economic, hedonistic, and altruistic investors. Journal of Business Research 36(1), 25-35. http://dx.doi.org/10.1016/0148-2963(95)00160-3

Suomi, M., \& A. Lumme. (1994). Yksityishenkilo“ iden pa“ a” omasijoittaminen Suomessa. Informal venture capital in Findland. SITRA, 141, Helsinki.

Sussland, Willy A. Business value and corporate governance: a new approach. The Journal of Business Strategy, 25(1), 49-56.

Sutter, Daniel. (1999). Politician's motives in the rent seeking society. Managerial Finance, 25(3-4), 38-52. http://dx.doi.org/10.1108/03074359910766424

Tadic, 1. (2010): Human Capital Practices in Different Industries in Croatia. The Business Review Cambridge, 15(2), 239-246

Talbot, Philip A. (2003). Management organisational history-a military lesson?. Journal of European Industrial Training, 27(7), 330-340. http://dx.doi.org/10.1108/03090590310490007

Taluni, T., Van Ryzin, GJ. (2005). The Theory and Practice of Revenue Management.New York. Springer.

Tashiro, Y. (1999).Business angels in Japan. Venture Capital, 1(3), 259-273. http://dx.doi.org/10.1080/136910699295893

Tetlock, P.C. (2007). Giving content to investor sentiment: The role of media in the stock $\begin{array}{llll}\text { market. } \quad \text { Journal } & \text { Finance, } & 62, & 1139-1168 .\end{array}$ http://dx.doi.org/10.1111/j.1540-6261.2007.01232.x

Tilson, Whitney, \& Heins, John (2011). The Value of Shareholder Activism. Kiplinger's Personal Finance, 65(5).

Tim,Baldenius.,Nahum,Melumad., Xiaojing Meng. (2010). Advising and Monitoring CEOs: The Dual Role of Boards. AAA 2011 Management Accounting Section Meeting Paper.

Ting, Hsiu-I. (2006). When Does Corporate Governance Add Value? The Business Review, Cambridge, 5(2), 196-203.

Turner, Matt. (2007). Setting Shareholder-Focused Performance Targets. Financial Executive, 23(7), 32-34 


\section{Macrothink}

Business and Economic Research ISSN 2162-4860 2014, Vol. 4, No. 1

Van Osnabrugge, M. (1998). Do serial and non-serial investors behave differently? An empiricaland theoretical analysis. Entrepreneurship Theory and Practice, 22(4), 23-42

Van Osnabrugge, Mark, \& Robinson, Robert (2000). Angel Investing: Matching Start-Up Funds with Start-Up Companies. San Francisco, CA: Jossey-Bass.

Velasquez, M. (1983). Why Corporations are not morally responsible for what they do, Business and Professional Ethics Journal, 2(Spring), 1-18. http://dx.doi.org/10.5840/bpej19832349

Vogel, David. (1983). Trends in Shareholder Activism: 1970-1982. California Management Review, 25, 68. http://dx.doi.org/10.2307/41165017

Waddock, S. A., \& Graves, S. B. (1997a). The corporate social performance-financial performance link. Strategic Management Journal, 18(4), 303-319. http://dx.doi.org/10.1002/(SICI)1097-0266(199704)18:4<303::AID-SMJ869>3.0.CO;2-G

Waddock, S. A., \& Graves, S. B. (1997b). Quality of management and quality of stakeholder relations: Are they synonymous? Business \& Society, 36(3), 250-279. http://dx.doi.org/10.1177/000765039703600303

Wetzel, W. E. (1981).Informal risk capital in New England. In Frontiers of entrepreneurship research, ed. K. Vesper, 271-45, Wellesley, MA: Babson College.

Wetzel, William E., \& Freear, John (1996). Promoting informal venture capital in the United States: reflections on the history of the Venture Capital Network. In Harrison, Richard T., \& Mason, Colin M. (Ed.), Informal venture capital: Evaluating the impact of business introduction services (pp. 61-74). New York: Prentice-Halll Woodhead Faulker.

Wilmot, Stephen. (2001). Corporate moral responsibility: What can we infer from our understanding of organisations?. Journal of Business Ethics, 30(2), 161-169. http://dx.doi.org/10.1023/A:1006346125667

Yu, J. C. P., Wee, H. M., \& Su, G. B. (2012). Revisiting revenue management for remanufactured products. International Journal of Systems Science, 1-6.

Zeghal, D., \& Maaloul, A. (2010). Analysing value added as an indicator of intellectual capital and its consequences on company performance, Journal of Intellectual Capital, 1(1), $39-60$

Zhao, D. (2011). Research and Application on Fixed Asset Management System. Techniques of Automation and Applications, 9.

\section{Copyright Disclaimer}

Copyright reserved by the author(s).

This paper is an open-access paper distributed under the terms and conditions of the Creative Commons Attribution license (http://creativecommons.org/licenses/by/3.0/). 